\author{
KRZYSZTOF OŻÓG \\ Uniwersytet Jagielloński, Kraków
}

\title{
O NAUKOWYM PLONIE 600. ROCZNICY BITWY POD GRUNWALDEM W HISTORIOGRAFII
}

W polskiej historiografii badania nad stosunkami Polski z zakonem krzyżackim były i są nadal stymulowane w dużej mierze przez okrągłe rocznice ważnych wydarzeń, np. bitwy płowieckiej (1331), procesu warszawskiego (1339), bitwy grunwaldzkiej (1410), drugiego traktatu toruńskiego (1466) i hołdu pruskiego (1525). Przed obchodami 600. rocznicy bitwy pod Grunwaldem w historiografii było kilka monograficznych opracowań poświęconych samej bitwie oraz wojnie z zakonem w latach 14091411, do których należy zaliczyć przede wszystkim dzieła: Stefana M. Kuczyńskiego, Mečislovasa Jučasa, Svena Ekdahla, Andrzeja Nadolskiego, Mariana Biskupa i Williama Urbana ${ }^{1}$. Obok nich narosło wiele analitycznych studiów i przyczynków dotyczących rozmaitych aspektów wojny lat 1409-1411, a także ukazało się szereg edycji nowo odkrytych źródeł związanych z tym konfliktem ${ }^{2}$. $Z$ przytoczonego powyżej zestawienia wynika, że w dotychczasowej historiografii ostatnią pełną, analityczną monografią tej wojny była praca S.M. Kuczyńskiego. Nie wykorzystał on

${ }^{1}$ S. M. Kuczyński, Wielka wojna z Zakonem Krzyżackim w latach 1409-1411, Warszawa 1955 (nast. wyd. uzup. 1960, 1966, 1980, 1987); M. Jučas, Žalgirio mūšis, Vilnius 1959 (nast. wyd. 1960, 1990, 1999; polski przekład Grunwald 1410, Kraków 2010); S. Ekdahl, Die Schlacht bei Tannenberg 1410. Quellenkritische Untersuchungen, t. 1: Einfürung und Quellenlage, Berlin 1982 (polski przekład: Grunwald 1410. Studia nad tradycją i źródłami, Kraków 2010); A. Nadolski, Grunwald. Wybrane problemy, Olsztyn 1990; idem, Grunwald 1410, Warszawa 1993; M. Biskup, Grunwaldzka bitwa. Geneza - przebieg - znaczenie - tradycje, Warszawa 1991; W. Urban, Tannenberg and After. Lithuania, Poland and the Teutonic Order in Search of Immortality, Chicago 2002.

${ }^{2}$ Zob.S. Jóźwiak, Rozwój badań nad wielka wojna polsko-litewsko-krzyżacka (1409-1411) w historiografii ostatniego półwiecza, „Komunikaty Mazursko-Warmińskie” 2009, 2 (264), s. 209-223. 
jednak wielu archiwalnych źródeł krzyżackich. Natomiast pozostałe prace koncentrowały się głównie na bitwie pod Grunwaldem lub wybranej problematyce. Potrzeba nowoczesnego i wszechstronnego opracowania kampanii letniej 1410 r., jak i dziejów całego konfliktu polsko-litewsko-krzyżackiego w latach 1409-1411 stała się widoczna w dwóch ostatnich dekadach XX w. Przygotowania do takiego dzieła rozpoczął S. Ekdahl, który najpierw wydał krytycznie Banderia Prutenorum Jana Długosza, a potem opublikował gruntowne studium o źródłach do bitwy pod Grunwaldem i zapowiedział przyszłą monografię na jej temat, czego jednak nie zrealizował do dzisiaj'. Pozostał jednak wierny problematyce grunwaldzkiej, dokonał bowiem edycji Księgi żołdu Zakonu Niemieckiego 1410/ $1411^{4} \mathrm{i}$ opublikował szereg artykułów dotyczących rozmaitych aspektów kampanii 1410 r. ${ }^{5} \mathrm{~W}$ tym samym czasie A. Nadolski również pracował nad najważniejszymi problemami batalii grunwaldzkiej, publikując na ten temat tom studiów oraz książkę popularnonaukową. Nie zdążył przygotować pełnej monografii bitwy pod Grunwaldem ${ }^{6}$. Do zagadnień konfliktu z zakonem nawiązywał w swych badaniach również M. Biskup, który tematyce grunwaldzkiej poświęcił odrębną książkę przeznaczoną dla szerszego grona czytelników ${ }^{7}$.

Sześćsetna rocznica bitwy pod Grunwaldem obchodzona była w 2010 r. $z$ wielkim rozmachem w Polsce i na Litwie, najważniejsze zaś polskie wydarzenia rocznicowe objęte zostały patronatem Prezydenta RP.W środowisku naukowym z tej okazji zostały zainicjowane badania, których istotniejsze rezultaty będą przedmiotem niniejszego artykułu. Zainteresowania badaczy skupiały się nie tylko na wojnie Polski i Litwy z zakonem krzyżackim (1409-1411) i bitwie na polach Grunwaldu oraz sytuacji stron konfliktu w pierwszych dekadach XV w., ale również na rozbudowanej tradycji zwycięstwa grunwaldzkiego w Polsce, na Litwie, Białorusi, a także w Niemczech i jej różnorakich funkcjach od XV do początku XXI w. Opublikowanych zostało kilka tomów studiów, stanowiących pokłosie projektów badawczych,

${ }^{3}$ S. Ekdahl, Die „Banderia Prutenorum” des Jan Długosz - eine Quelle zur Schlacht bei Tannenberg 1410, Göttingen 1976; idem, Die Schlacht bei Tannenberg.

${ }^{4}$ Das Soldbuch des Deutschen Ordens 1410/1411. Die Abrechnungen für die Soldtruppen, cz. 1: Text mit Anhang und Erläuterungen, red. S. Ekdahl, Köln-Wien 1988.

${ }^{5}$ Zob. Verzeichnis der wissenschaftlichen Veröffentlichungen von Sven Ekdahl 1963-2010 (mit Ausnahme von Besprechungen), w: Beiträge zur Militärgeschichte des Preussenlandes von der Ordenszeit bis zum Zeitalter der Weltkriege, red. B. Jähnig, Marburg 2010, Tagungsberichte der Historischen Kommission für Ost- und Westpreussische Landesforschung, 25, s. 13-24.

${ }^{6}$ Por. przyp. 1.

${ }^{7}$ M. Biskup, Grunwaldzka bitwa; idem, Wojny Polski z Zakonem Krzyżackim 1308-1521, Gdańsk 1993, s. 38-94. 
wystaw oraz konferencji naukowych związanych z rocznicą grunwaldz$\mathrm{ką}^{8}$. Ponadto ukazało się szereg artykułów i studiów w czasopismach naukowych. Niejako zwieńczeniem tych publikacji stała się bardzo obszerna monografia całej wojny z lat 1409-1411 pióra czterech mediewistów z Torunia i Gdańska: Sławomira Jóźwiaka, Krzysztofa Kwiatkowskiego, Adama Szwedy, Sobiesława Szybkowskiego, Wojna Polski i Litwy z zakonem krzyżackim w latach 1409-1411 (Malbork 2010).

Rekonesans po rocznicowym plonie naukowym zostanie ujęty problemowo, poczynając od prac dotyczących sytuacji Królestwa Polskiego, Wielkiego Księstwa Litewskiego, państwa pruskiego zakonu krzyżackiego oraz ich sąsiadów przed wojną 1409-1411 w szerokim kontekście ówczesnej Europy, poprzez studia poświęcone tej wojnie od wypowiedzenia jej 6 sierpnia 1409 r. do pokoju toruńskiego 1 lutego 1411 r., kończąc na literaturze ukazującej tradycję bitwy grunwaldzkiej od XV do początku XXI w. oraz jej różnorodne aspekty i funkcje w Polsce, na Litwie, Białorusi i w Niemczech ${ }^{9}$.

Stosunki polsko-litewsko-krzyżackie przed rokiem 1409 i europejski kontekst wojny 1409-1411

Za istotne osiągnięcie rocznicowej historiografii należy uznać artykuły omawiające sytuację Polski, Litwy i zakonu krzyżackiego w XIV i na początku XV w. oraz problemy wojny i pokoju w kontekście późnośredniowiecznej Europy. Wiele uwagi tej problematyce poświęcono we wspomnianym wyżej tomie studiów Tannenberg - Grunwald - Žalgiris 1410: Krieg und Frieden im späten Mittelalter, stanowiącym pokłosie międzynarodowej konferencji odbytej w Wilnie 21-23 października 2010 r. ${ }^{10}$ Uwaga badaczy z Niemiec,

${ }^{8}$ Tradycje kulturowe i historyczne ziem pruskich. Krajobraz grunwaldzki w dziejach polsko-krzyżackich i polsko-niemieckich na przestrzeni wieków. Wokół mitów i rzeczywistości, red.J. Gancewski, Olsztyn 2009; Na znak świetnego zwycięstwa. W sześćsetna rocznicę bitwy pod Grunwaldem. Katalog wystawy 15 lipca-30 września 2010. Zamek Królewski na Wawelu. Państwowe Zbiory Sztuki, t. 1: Studia, t. 2: Noty katalogowe, red. D. Nowacki, Kraków 2010; Bitwa grunwaldzka w historii, tradycji i kulturze 1410-2010, red. T. Ossowski, Kielce 2010; „Annales Universitatis Paedagogicae Cracoviensis" 99, Studia Historica 11: Bitwa pod Grunwaldem whistorii i tradycji Polski i Litwy, 2011 (dalej: Bitwa pod Grunwaldem w historii Polski i Litwy); Tannenberg - Grunwald - Žalgiris 1410: Krieg und Frieden im späten Mittelalter, red. W.Paravicini, R. Petrauskas, G. Vercamer, Wiesbaden 2012, Deutsches Historisches Institut Warschau, Quellen und Studien 26; Wojna, pamięć, tożsamość. O bitwach i mitach bitewnych, red. J. M. Piskorski, Warszawa 2012.

${ }^{9} \mathrm{~W}$ niniejszym przeglądzie nie zostały uwzględnione prace i pokonferencyjne zbiory studiów poświęcone problematyce grunwaldzkiej, które znajdują się jeszcze w druku.

${ }^{10}$ Por. przyp. 8. 
Polski, Litwy i Francji skupiała się na pięciu ważnych kwestiach: sytuacji Europy Środkowo-Wschodniej na przełomie XIV i XV w., sztuce wojennej w późnym średniowieczu, formach kontaktów pokojowych (zawieraniu układów pokojowych), samej bitwie pod Grunwaldem i pamięci o niej. W ramach pierwszego zagadnienia Martin Kintzinger scharakteryzował ostatnie badania nad powiązaniami między Zachodem i Wschodem Europy w średniowieczu i wskazał na rolę dynastii Luksemburgów, która przyczyniła się w XIV i XV w. do zintensyfikowania wzajemnych kontaktów ${ }^{11}$. Zdaniem niemieckiego mediewisty sobory z pierwszej połowy XV w., w szczególności w Konstancji, umożliwiły polityczną komunikację w ramach całej Europy i równoprawne uczestnictwo w obradach i dyskusjach przedstawicieli potęg chrześcijańskich z Zachodu i Wschodu. Podkreślił też rolę Pawła Włodkowica w rozwijaniu koncepcji prawa narodów (ius gentium). Z kolei Thomas Wünsch odniósł się do poglądów Włodkowica na temat sposobów rozwiązania konfliktu z zakonem krzyżackim, wyrażonych w liście do Zbigniewa Oleśnickiego z 1432 r. ${ }^{12}$ Uznał on krakowskiego prawnika u schyłku życia za protagonistę „,realizmu politycznego" w stosunkach polsko-krzyżackich i załatwiania sporów międzynarodowych na drodze postępowania sądowego. Następnie Stephen C. Rowell omówił początki unii polsko-litewskiej, koncentrując swoje wywody na kościelnej polityce Jagiełły i Witolda w Wielkim Księstwie Litewskim, militarnym oraz dyplomatycznym współdziałaniu Polski i Litwy, a także kształtowaniu się dynastii jagiellońskiej i jej interesów ${ }^{13}$. Natomiast Artūras Dubonis ukazał rolę terytoriów pogranicznych między Litwą a władztwem zakonu krzyżackiego w różnorodnych kontaktach obu stron w latach $1290-1422^{14}$. Podkreślił przy tym znaczenie rozwoju osadnictwa i wynikających z tego procesu zmian etnicznych na pograniczu.

Druga część tomu zawiera artykuły poświęcone sztuce prowadzenia wojny w późnym średniowieczu w Europie. Wybitny znawca tej problematyki Philippe Contamine scharakteryzował na wybranych przykładach bitew stoczonych we Francji w XV w. sposoby obrazowania ich

${ }^{11}$ M. Kintzinger, Perspektivenwechsel. Internationale Beziehungen zwischen West- und Osteuropa im Spätmittelalter, w: Tannenberg - Grunwald - Žalgiris 1410, s. 13-26.

${ }^{12}$ T. Wünsch, Paulus Wladimiri und die Genese des "realistischen Denkens” in der Lehre von den internationalen Beziehungen: Der Krieg zwischen Polen und dem Deutschen Orden als Stimulus für ein neues politiktheoretisches Paradigma, w: Tannenberg - Grunwald - Žalgiris 1410, s. 27-42.

${ }^{13}$ S.C. Rowell, The Grand Duchy of Lithuania and the Beginning of the Union with Poland: the Background of Grunwald, w: Tannenberg - Grunwald - Žalgiris 1410, s. 43-51.

${ }^{14}$ A. Dubonis, Das Grenzgebiet zwischen Litauen und dem Deutschen Orden: soziale, wirtschaftliche, administrative, ethnische und kulturelle Kommunikation in den Jahren 1290-1422, w: Tannenberg - Grunwald - Žalgiris 1410, s. 53-65. 
przebiegu w źródłach narracyjnych oraz ikonograficznych, szczególnie w relacjach ustnych i pisemnych uczestników, listach wysyłanych z pól bitewnych, opisach historiografów, pamiętnikach oraz na obrazach i miniaturach, a także podkreślił ich rolę propagandową ${ }^{15}$. $Z$ kolei Hans-Henning Kortüm zanalizował wybrane aspekty polskich i krzyżackich dziejopisarskich przekazów o bitwie grunwaldzkiej w kontekście typowej późnośredniowiecznej historiografii o wojnach i bitwach ${ }^{16}$. Natomiast Malte Prietzel omówił zmiany w prowadzeniu wojen w Europie w XIV i XV w. wynikające $\mathrm{z}$ używania piechoty oraz artylerii ${ }^{17}$, zaś Jürgen Sarnowsky koszty ówczesnych wojen ${ }^{18}$. Uwe Tresp ukazał problem zaciężnych z ziem Korony św. Wacława w służbie polskiej i krzyżackiej w dobie wojny $1409-1411^{19}$, a Darius Baronas litewską sztukę wojenną w XIII w. i jej ewolucję pod wpływem wojen z zakonem krzyżackim w drugiej połowie XIV i na początku XV w. ${ }^{20}$ Interesujące ustalenia na temat służby rycerskiej wolnych (Freie) w państwie zakonnym w Prusach i ich liczebności na początku XV w. poczynił Grischa Vercamer na podstawie Wielkiej księgi czynszów Zakonu (Das grosse Zinsbuch des Deutschen Ritterordens) z 1414 r. Stwierdził on, że ta grupa społeczna była wówczas podstawą militarnej organizacji władztwa krzyżackiego i liczyła 4350 ludzi, którzy byli zobowiązani do bezpłatnej służby wojennej na rzecz zakonu każdego roku w okresie 4-6 tygodni. Stanowili oni prawie jedną trzecią całej armii zakonu w kampanii 1410 r. Skorygował tym samym istotnie dawne ustalenia Friedricha Benninghovena, który obliczył, że było ich wówczas $5872^{21}$. W ostatnim artykule tej części tomu S. Jóźwiak zaprezentował funkcjonowanie i działania

${ }^{15}$ P. Contamine, Die Schlacht im Abendland am Ende des Mittelalters: Vorstellung, Kampfhandlung, Bericht, Bild und Erinnerung, w: Tannenberg - Grunwald - Žalgiris 1410, s. 69-88.

${ }^{16}$ H.-H. Kortüm, Die Tannenbergschlacht im Kontext der spätmittelalterlichen Kriegsbzw. Schlachtgeschichte, w: Tannenberg - Grunwald - Žalgiris 1410, s. 89-101.

${ }^{17}$ M. Prietzel, Veränderungen in der spätmittelalterlichen Kriegsführung, w: Tannenberg - Grunwald - Žalgiris 1410, s. 103-121.

${ }^{18} \mathrm{~J}$. Sarnowsky, Wirtschaftliche Aspekte der Geschichte der Kriege am Beginn des 15. Jahrhunderts, w: Tannenberg - Grunwald - Žalgiris 1410, s. 123-134.

${ }^{19}$ U. Tresp, Söldner aus dem Ländern der Böhmischen Krone in den Kriegen zwischen dem Deutschen Orden und Polen-Litauen zu Beginn des 15. Jahrhunderts, w: Tannenberg Grunwald - Žalgiris 1410, s. 135-158.

${ }^{20}$ D. Baronas, Der Kontext der litauischen Kriegskunst des 13. Jahrhunderts und die militärischen Innovationen von der zweiten Hälfte des 14. Jahrhunderts bis zum Beginn des 15. Jahrhunderts, w: Tannenberg - Grunwald - Žalgiris 1410, s. 159-173.

${ }^{21} \mathrm{G}$. Vercamer, Die Freien im Deutschordensland Preussen als militärischer Rückhalt Ende des 14.-Anfang des 15. Jahrhunderts, w: Tannenberg - Grunwald - Žalgiris 1410, s. 175189; zob. też idem, Man darf die schlafenden Hunde nicht wecken. Die militärische, soziale und politische Bedeutung der Freien im östlichen Ordensland Preussen für den Deutschen Orden, w: Beiträge zur Militärgeschichte des Preussenlandes, s. 53-74. 
wywiadu krzyżackiego w dobie wojny 1409-1411 22. Trzecia część omawianego tomu mieści studia dotyczące głównie różnorodnych działań dyplomatycznych w stosunkach Polski i Litwy z zakonem krzyżackim. Najpierw Klaus Neitmann przedstawił dyplomatyczną procedurę stosowaną przy zawieraniu wieczystych traktatów pokojowych między zakonem niemieckim w Prusach a Królestwem Polskim i Wielkim Księstwem Litewskim w latach 1398-1435 ${ }^{23}$, a następnie Jean-Marie Moeglin nakreślił rolę arbitrażu (sądów polubownych) w rozwiązywaniu międzynarodowych konfliktów w średniowiecznej Europie ${ }^{24}$, zaś A. Szweda omówił różne formy pokojowych kontaktów dyplomatycznych polsko-krzyżackich u schyłku XIV i w pierwszej połowie XV w. Ustalenia tego ostatniego historyka oparte są na gruntownych badaniach opublikowanych w obszernej monografii na temat organizacji i techniki działania polskiej dyplomacji w odniesieniu do zakonu krzyżackiego w Prusach od początku rządów Władysława Jagiełły w Królestwie Polskim do wybuchu wojny trzynastoletniej ${ }^{25}$. Z kolei Rimvydas Petrauskas prześledził ewolucję w stosunkach politycznych litewsko-krzyżackich od wrogości i wojny do przymierza. Podkreślał przy tym złożone mechanizmy wzajemnych stosunków i poważny wpływ zakonu na litewskie państwo i jego elitę władzy, starając się podważyć zakorzenione w historiografii poglądy o „odwiecznej” wojnie narodu litewskiego z Krzyżakami ${ }^{26}$. Natomiast Werner Paravicini ukazał proces zmian w postrzeganiu Litwinów: od barbarzyńskich, pogańskich przeciwników poprzez godnych szacunku przeciwników do pełnoprawnych członków zachodniego świata chrześcijańskiego ${ }^{27}$.

${ }^{22}$ S. Jóźwiak, Spionage zur Zeit des polnisch-litauischen Krieges gegen Deutschen Orden 1409-1411, w: Tannenberg - Grunwald - Žalgiris 1410, s. 191-197.

${ }^{23}$ K. Neitmann, Vom „ewigen Frieden”. Die Kunst des Friedensschlusses zwischen dem Deutschen Orden und Polen-Litauen 1398-1435, w: Tannenberg - Grunwald - Žalgiris 1410, s. 201-209.

${ }^{24} \mathrm{~J} .-\mathrm{M}$. Moeglin, Krieg und Vermittlungsverfahren in Europa in den letzten Jahrhunderten des Mittelalters, w: Tannenberg - Grunwald - Žalgiris 1410, s. 211-222. Przy tej okazji wypada zwrócić uwagę na rozprawę Rafała Wojciechowskiego: Arbitraż w doktrynie prawnej średniowiecza (Wrocław 2010), w której na podstawie prawa rzymskiego (kodyfikacji justyniańskiej) i kanonicznego oraz pism prawników średniowiecznych wnikliwie ukazane zostały najistotniejsze elementy doktryny prawnej dotyczącej postępowania polubownego.

${ }^{25}$ A. Szweda, Polen und der Deutsche Orden - Botenwesen und friedliche Verhandlungen, w: Tannenberg - Grunwald - Žalgiris 1410, s. 223-236; idem, Organizacja i technika dyplomacji polskiej w stosunkach z zakonem krzyżackim w Prusach w latach 1386-1454, Torun 2009.

${ }^{26}$ R. Petrauskas, Litauen und der Deutsche Orden: Vom Feind zum Verbündeten, w: Tannenberg - Grunwald - Žalgiris 1410, s. 237-251.

${ }^{27}$ W. Paravicini, Litauer: vom heidnischen Gegner zum adligen Standesgenossen, w: Tannenberg - Grunwald - Žalgiris 1410, s. 253-282. 
W omawianym powyżej tomie brak jednak studiów analizujących wszechstronnie przyczyny wojny 1409-1411, a także dyplomatyczne zabiegi obu stron przed jej wybuchem. Wnikliwe badania nad grą dyplomacji krzyżackiej i polskiej w sprawie powstania na Żmudzi w ostatnich miesiącach przed rozpoczęciem wojny przeprowadzili S. Jóźwiak i A. Szweda. W opublikowanym w 2007 r. artykule stwierdzili, że Władysław Jagiełło, współdziałając z Witoldem, świadomie dążył poprzez działania dyplomatyczne do sprowokowania wielkiego mistrza Ulryka von Jungingena do ataku na ziemie polskie i wywołania wojny, aby zyskać wsparcie społeczeństwa polskiego w polityce antykrzyżackiej i rozstrzygnąć ostatecznie kwestię Żmudzi na korzyść Litwy ${ }^{28}$. Jagiełło chciał również zdyskredytować zakon w opinii międzynarodowej. Na podstawie źródeł głównie proweniencji krzyżackiej wspomniani mediewiści gruntownie zanalizowali działania dyplomatyczne króla po wybuchu powstania na Żmudzi od czerwca do sierpnia 1409 r., a w szczególności poselstwo do wielkiego mistrza z arcybiskupem gnieźnieńskim Mikołajem Kurowskim, wojewodą kaliskim Maciejem z Wąsoczy i kasztelanem nakielskim Wincenty z Granowa na czele. Do tej pory było ono omawiane w literaturze dość jednostronnie, głównie za przekazem Długosza. Zawoalowane groźby ze strony polskiej kierowane pod adresem krzyżackim, wysiłki arcybiskupa, aby uniknać jasnego określenia stanowiska króla Władysława wobec kwestii żmudzkiej charakteryzowały, zdaniem S. Jóźwiaka i A. Szwedy, postępowanie poselstwa polskiego w Malborku, które skłoniło władze zakonu do podjęcia decyzji o wypowiedzeniu wojny Królestwu Polskiemu ${ }^{29}$. Z kolei K. Kwiatkowski w odrębnym studium poddał gruntownej analizie okoliczności wypowiedzenia wojny przez wielkiego mistrza królowi polskiemu oraz list wypowiedni Ulryka von Jungingena z 6 sierpnia 1409 r. i jego drogę do rąk Władysława Jagiełły ${ }^{30}$. Zdaniem tego badacza król otrzymał ów list 14 sierpnia, siły zaś krzyżackie po mobilizacji uderzyły na ziemie polskie 16 sierpnia. Na uwagę zasługuje również artykuł Romana Czai o relacjach między zakonem a jego poddanymi w Prusach za rządów dwóch wielkich mistrzów Konrada i Ulryka von Jungingen (1393-1410) ${ }^{31}$. Stwierdził on, że przed 1410 r. nie było poważniejszych konfliktów między

${ }^{28}$ S. Jóźwiak, A. Szweda, Przed „wielka wojna”. Polsko-krzyżacka rozgrywka dyplomatyczna w czerwcu-sierpniu 1409 roku, RH 73, 2007, s. 139-164.

${ }^{29}$ Ibidem, s. 154-164.

${ }^{30} \mathrm{~K}$. Kwiatkowski, Okoliczności wypowiedzenia wojny królowi polskiemu Władysławowi II przez wielkiego mistrza Zakonu Niemieckiego Ulricha von Jungingen w sierpniu 1409 roku, ZH 74, 2009, 3, s. 7-36.

${ }^{31}$ R. Czaja, Gesellschaft und Landesherr im Ordensland Preussen zu Beginn des 15. Jahrhunderts, ZH 75, 2010, 4, s. 19-31. 
zakonem a miastami i rycerstwem, widoczne są zaś przejawy współpracy stanów pruskich z Krzyżakami. Tym samym dowiódł, że zmiana postawy dużych miast pruskich oraz rycerstwa po klęsce grunwaldzkiej względem władcy terytorialnego i przejście na stronę króla polskiego wynikały z rozmiarów klęski zakonu i braku wiary w odbudowę przezeń swej władzy w Prusach.

Wszechstronne omówienie sytuacji politycznej Królestwa Polskiego, Wielkiego Księstwa Litewskiego oraz państwa zakonu krzyżackiego w Europie Środkowo-Wschodniej i ich wzajemne stosunki od zawarcia unii polsko-litewskiej i chrztu Litwy do 1409 r. znalazło się we wspomnianej wyżej monumentalnej monografii wojny lat 1409-1411 pióra S. Jóźwiaka, K. Kwiatkowskiego, S. Szybkowskiego i A. Szwedy. Autorzy postawili sobie za główny cel „przeprowadzenie gruntownych badań nad przebiegiem konfliktu 1409-1411 r. w oparciu o krytyczną analizę możliwie wszystkich zachowanych przekazów źródłowych pozostawionych przez mniej lub bardziej zaangażowane w niego strony, nie wchodząc jednocześnie w żadne nacjonalistyczno-ideologiczne dysputy, które dotąd utrudniały, a wręcz uniemożliwiały obiektywne spojrzenie na to wydarzenie" ${ }^{32}$. Wskazali przy tym, że możliwe jest „sprostowanie funkcjonujących dotąd nieścisłości, uproszczeń, bądź zwykłej nieprawdy", a także różnorodnych mitów ${ }^{33}$. Na początku swych rozważań badacze zanegowali popularne w literaturze przedmiotu określenie konfliktu $\mathrm{z}$ lat 1409-1411: „wielka wojna”, słusznie dowodząc, że w źródłach odnosi się ono jedynie do bitwy grunwaldzkiej, a nie do całej wojny, i dlatego zrezygnowali z jego używania.

Obok sytuacji politycznej i działań dyplomatycznych obu stron autorzy wnikliwie scharakteryzowali narastanie konfliktu i postawy wobec niego społeczeństw polskiego, litewskiego i pruskiego ${ }^{34}$. W odniesieniu do polskiej elity S. Szybkowski stwierdził istotne zróżnicowanie w poglądach na stosunki z zakonem krzyżackim i dość powszechne przekonanie o potrzebie utrzymania dobrych stosunków z północnym sąsiadem. Zdecydowanie zakwestionował dotychczasowe stanowisko polskiej historiografii o wrogości całego społeczeństwa wobec Krzyżaków i dążeniu do militarnej konfrontacji z powodu doznanych przez Królestwo Polskie krzywd w przeszłości ${ }^{35}$. Natomiast niewiele wiadomo z powodu ubogich źródeł o stosunku do

${ }^{32}$ S. Jóźwiak, K. Kwiatkowski, A. Szweda, S. Szybkowski, Wojna Polski i Litwy z zakonem krzyżackim w latach 1409-1411, Malbork 2010, s. 11.

${ }^{33}$ Ibidem, s. 12.

${ }^{34}$ Ibidem, s. 35-116.

${ }^{35}$ Stanowisko episkopatu polskiego wobec konfliktu z zakonem w szerszej perspektywie czasu omówił w odrębnej pracy Tomasz Graff, Kościół wobec konfliktu z zako- 
konfliktu elity społeczeństwa litewskiego, a także o postawach rycerstwa i mieszczaństwa w Prusach zakonnych wobec Polski i Litwy. Niewątpliwie na Litwie istniała opozycja skupiona wokół Świdrygiełły, który w 1409 r. wystąpił przeciw Jagielle i Witoldowi, wiążąc się z Krzyżakami. S. Jóźwiak ukazał militarne przygotowania zakonu do wojny latem 1409 r. oraz plany strategiczne dowództwa krzyżackiego na początku sierpnia tr., zakładające uderzenie na ziemię dobrzyńską, Kujawy i Wielkopolskę, a także obronną strategię strony polskiej na pograniczu z państwem zakonu.

Od wypowiedzenia wojny 6 sierpnia 1409 r. do zawarcia traktatu toruńskiego 1 lutego 1411 r.

Pierwsza faza wojny zakonu krzyżackiego z Królestwem Polskim i Wielkim Księstwem Litewskim od wystawienia przez wielkiego mistrza listu wypowiedniego 6 sierpnia 1409 r. do zawarcia rozejmu 8 października tr. nie była przedmiotem szczególniejszego zainteresowania historyków w związku z obchodzoną rocznicą, z wyjątkiem S. Jóźwiaka, A. Szwedy i S. Szybkowskiego, którzy poświęcili jej drugi rozdział omawianej monografii wojny 1409-1411 ${ }^{36}$. Na uwagę zasługują przede wszystkim ustalenia autorów dotyczące wypowiedzenia wojny przez wielkiego mistrza, rozpoczęcia i przebiegu działań militarnych oraz prowadzonych pertraktacji między stronami konfliktu, a także losów ziemi dobrzyńskiej pod okupacją krzyżacką. S. Jóźwiak i A. Szweda starali się uporządkować chronologię dostarczenia Władysławowi Jagielle listu z wypowiedzeniem wojny i rozpoczęcia ofensywy przez wojska zakonu na ziemie Królestwa Polskiego, gdyż po stronie polskiej pojawiły się oskarżenia, że Krzyżacy uderzyli, zanim doręczono królowi wspomniane pismo wielkiego mistrza. Zdołali ustalić, że Jagiełło otrzymał list wypowiedni 14 lub 15-16 sierpnia w Nowym Mieście Korczynie, wojska krzyżackie zaś przekroczyły granice Królestwa 16 sierpnia, uderzając na ziemię dobrzyńską, Krajnę i Kujawy. Poważne sukcesy militarne zakonu w drugiej połowie sierpnia skłoniły stronę polską do kontynuowania negocjacji z Krzyżakami. S.Jóźwiak dowiódł, że próbę mediacji podjął na początku września 1409 r. arcybiskup M. Kurowski celem zawarcia rozejmu. Do negocjacji doszło po 15 września tr. w Radzyniu, gdzie wielki mistrz przedstawił stronie polskiej warunki pokoju, które jednak nie zostały ostatecznie zaakceptowane przez króla i panów koronnych,Jagiełło zaś zdecydował się na kontrofensywę na Kujawach i przerwanie rozmów. Po

nem krzyżackim w XV wieku. Studium z dziejów kultury politycznej polskiego episkopatu, Kraków 2010.

${ }^{36}$ S. Jóźwiak, K. Kwiatkowski, A. Szweda, S. Szybkowski, op. cit., s. 117-176. 
odzyskaniu Bydgoszczy (miasta i zamku), przy pośrednictwie czeskim 8 października 1409 r. nastąpiło zawarcie rozejmu polsko-krzyżackiego, który, jak stwierdził Autor, generalnie był przez obie strony przestrzegany, ale nie obejmował on Litwy, o czym świadczą akcje militarne zakonu, w tym próba pochwycenia samego Witolda przez nagły atak wielkiego marszałka Fryderyka von Wallenrode w marcu 1410 r. w głąb ziem litewskich. Z kolei S. Szybkowski wnikliwie zanalizował sytuację w okupowanej przez wojska zakonne ziemi dobrzyńskiej, ukazując postawy tamtejszej szlachty wobec Krzyżaków w nawiązaniu do okresu 1392-1405, kiedy terytorium to pozostawało pod ich władzą, a także politykę władz zakonu, które starały się pozyskać szlachtę dobrzyńską przywilejami ${ }^{37}$.

Działania dyplomatyczne i przygotowania militarne obu stron konfliktu w jesieni 1409 r. i na wiosnę 1410 r. stały się przedmiotem trzeciego rozdziału omawianej monografii pióra S. Jóźwiaka, A. Szwedy i S. Szybkowskiego ${ }^{38}$. Na mocy układu rozejmowego z 8 października 1409 r. konflikt polsko-krzyżacki miał zostać rozstrzygnięty do 9 lutego następnego roku przez Wacława IV, króla czeskiego, jako sędziego polubownego, a obie strony zobowiązały się przyjąć i wykonać jego orzeczenie. A. Szweda dokładnie rozpatrzył na podstawie wszystkich zachowanych źródeł postępowanie Wacława IV jako sędziego polubownego (wyłączono zeń Witolda, gdyż nie był stroną w układzie rozejmowym) i jego wyrok. Najpierw ustalił, że wyrok został ogłoszony nie 15 lutego, jak dotąd przyjmowała zdecydowana większość historyków za relacją Długosza, ale 8 lutego, co poświadczają wiarygodne źródła krzyżackie ${ }^{39}$. Następnie dokonał precyzyjnej analizy treści orzeczenia Wacława IV, stwierdzając, że przysądzając Żmudź zakonowi, a ziemię dobrzyńską Królestwu Polskiemu, „wyrokował on w duchu formalnego poszanowania istniejących umów między Polską, Litwą a zakonem krzyżackim". Takie stanowisko arbitra, jego zdaniem, „faworyzowało Krzyżaków, gdyż to strona polsko-litewska dążyła

${ }^{37}$ Problem prokrzyżacko nastawionej grupy rycerstwa w ziemi dobrzyńskiej i jej losów w latach wojny 1409-1411 oraz po zawarciu traktatu toruńskiego S. Szybkowski rozważył również w odrębnych studiach. Zob. idem, Świadkowie przywileju wielkiego mistrza Ulryka von Jungingen $z 28$ X 1409 roku. Z badań nad prokrzyżacka orientacja wśród szlachty dobrzyńskiej w okresie wojny 1409-1411, ZH 75, 2010, 2, s. 23-46; idem, Krzyżacy $i$ ich dobrzyńscy poplecznicy w latach 1405-1413. Z badań nad polsko-pruskimi zwiazkami transgranicznymi na początku XV wieku, „Komunikaty Mazursko-Warmińskie” 2010, 3 (269), s. 281-300.

38 S. Jóźwiak, K. Kwiatkowski, A. Szweda, S. Szybkowski, op. cit., s. 177-237.

${ }^{39}$ Do takiego samego ustalenia doszedł również S. Ekdahl. Zob. idem, Die Söldnerwerbungen des Deutschen Ordens für einen geplanten Angriff auf Polen am 1. Juni 1410. Ein Beitrag zur Vorgeschichte der Schlacht bei Tannenberg, w: Beiträge zur Militärgeschichte des Preussenlandes, s. 89-90; idem, W przededniu bitwy grunwaldzkiej. Dyplomacja i werbowanie żotnierzy zaciężnych w czerwcu 1410 r., w: Wojna, pamięć, tożsamość, s. 82-83. 
do zmiany status quo"40. A. Szweda wyraźnie zdystansował się od emocjonalnego przekazu Długosza o wielce niesprawiedliwym wyroku, który często bezkrytycznie był powtarzany w literaturze przedmiotu. Jagiełło nie uznał orzeczenia Wacława IV, albowiem wyraźnie dążył wraz z Witoldem do wznowienia działań militarnych po upływie rozejmu. $Z$ kolei A. Szweda i S. Szybkowski zaprezentowali dyplomatyczno-propagandową konfrontację Polski z zakonem na dworach europejskich i w kurii rzymskiej, sojusze militarne zawarte przez obie strony konfliktu, S. Jóźwiak zaś ukazał koncepcje i plany akcji militarnych przygotowywane w okresie trwania rozejmu przez króla i wielkiego mistrza. Według tego mediewisty zakon, inaczej niż w 1409 r., nie planował działań ofensywnych wobec Królestwa Polskiego, a Ulryk von Jungingen i jego otoczenie żywiło nawet nadzieję na dyplomatyczne zakończenie konfliktu przy pośrednictwie Wacława IV lub Zygmunta Luksemburskiego. Natomiast Jagiełło i Witold konsekwentnie planowali i przygotowywali atak sił polsko-litewskich na państwo zakonne w Prusach i już wówczas polityczna i militarna inicjatywa w tym konflikcie wymknęła się z rąk krzyżackich. Znakomitej analizie poddał S. Jóźwiak nieliczne ślady źródłowe świadczące o intensywnych działaniach wywiadowczych zakonu i Polski, których celem było rozpoznanie zamierzeń militarnych przeciwnika.

Postępowaniem polubownym i wyrokiem Wacława IV Luksemburskiego w konflikcie polsko-litewsko-krzyżackim zajął się też czeski mediewista Martin $\mathrm{Nodl}^{41}$. Niezależnie od A. Szwedy podkreślił on formalno-prawne stanowisko Wacława IV przy rozstrzyganiu sporu polsko-krzyżackiego i dążenie do zachowania terytorialnego i prawnego status quo w stosunkach zakonu z Królestwem Polskim i Wielkim Księstwem Litewskim. Do problemu polityki Wacława IV wobec Polski w tym okresie nawiązuje również artykuł Jerzego Grygla,jednakże w swych wywodach idzie on za starszą literaturą przedmiotu ${ }^{42}$.

Intensywne badania S. Ekdahla nad zaciężnymi w służbie zakonu krzyżackiego w $1410 \mathrm{r}$. oraz sytuacją obu stron konfliktu przed bitwą grunwaldzką doprowadziły go do sformułowania koncepcji o planowanym na 1 czerwca 1410 r. przez wielkiego mistrza ataku na Królestwo Polskie, a więc jeszcze przed upływem rozejmu ${ }^{43}$. Stwierdził, że Ulryk

${ }^{40}$ S. Jóźwiak, K. Kwiatkowski, A. Szweda, S. Szybkowski, op. cit., s. 187.

${ }^{41}$ M. Nodl, Sędzia polubowny - Wacław IV. Międzynarodowe aspekty politycznej rywalizacji monarchii polsko-litewskiej i Zakonu Krzyżackiego, w: Bitwa grunwaldzka w historii, tradycji i kulturze, s. 21-31.

${ }^{42}$ J. Grygiel, Polska i Czechy w dobie bitwy grunwaldzkiej, w: Bitwa grunwaldzka whistorii, tradycji i kulturze, s.33-47.

${ }^{43}$ S. Ekdahl, Die Söldnerwerbungen des Deutschen, s. 89-102; idem, W przededniu bitwy 
von Jungingen w wielkiej tajemnicy prowadził wiosną tr. werbunek i pozyskał około 1800 zaciężnych (600 kopii), aby przeprowadzić nagły atak na ziemie polskie. Zdaniem szwedzkiego historyka Krzyżacy byli przekonani, że mają prawo do akcji militarnej przeciw Królestwu Polskiemu, ponieważ Jagiełło odrzucił polubowny wyrok Wacława IV i jego mediację. Król węgierski Zygmunt Luksemburski popierał plany wielkiego mistrza, ale chciał odegrać rolę mediatora w konflikcie i doprowadzić do bezpośrednich pertraktacji wielkiego mistrza z królem, dlatego zaproponował zjazd w Toruniu na 17 czerwca $1410 \mathrm{r}$. Władze zakonu nie mogły wystąpić przeciw tej propozycji i Ulryk von Jungingen zarządził po 11 maja zaprzestanie akcji werbunkowej zaciężnych w Czechach i Rzeszy oraz zrezygnował z uderzenia na Polskę. Jednakże po dwóch tygodniach zorientował się, że strona polsko-litewska intensywnie przygotowuje się do wojny, dlatego ponownie zarządził werbunek zaciężnych. S. Ekdahl uznał, iż sprzeczne decyzje wielkiego mistrza spowodowały, że znaczna część zaciężnych, którzy chcieli podjąć służbę w armii zakonu w drugiej połowie maja i na początku czerwca, zaoferowała swoją służbę królowi polskiemu i zaciągnęła się do jego wojska. To osłabiło możliwości militarne zakonu i poważnie przyczyniło się do klęski armii krzyżackiej na polach Grunwaldu. Ta koncepcja wymaga jednak szczegółowej dyskusji. Na podkreślenie zasługuje ustalenie szwedzkiego badacza, że w bitwie grunwaldzkiej wzięło udział 6400 zaciężnych po stronie krzyżackiej ${ }^{44}$. W 2010 r. S. Ekdahl ogłosił drukiem część drugą Księgi żołdu Zakonu Niemieckiego 1410/1411 zawierającą indeksy do opublikowanej w 1988 r. części pierwszej edycji tego źródła oraz aneksy z 23 dokumentami i listami zaciężnych krzyżackich ${ }^{45}$. W ramach części drugiej S. Ekdahl opracował niezwykle obszerny alfabetyczny indeks 822 zaciężnych w służbie zakonu w 1410 i 1411 r., podając liczne informacje biograficzne o każdym z nich. Dotyczą one przede wszystkim rodziny, pochodzenia, powiązań z zakonem oraz służby w Prusach w 1410 i na początku $1411 \mathrm{r} \cdot{ }^{46} \mathrm{Na}-$ tomiast we wprowadzeniu do tej części szwedzki historyk syntetycznie

grunwaldzkiej, s. 81-89; idem, Diplomatie und die Söldnerwerbung vor der Schlacht bei Žalgiris, ,Lietuvos Istorijos Studijos” 25, 2010, s. 48-61; idem, Das politische Umfeld und die Schlacht bei Tannenberg, w: Tannenberg/Grunwald 1410. Gesammelte Beiträge, Wien 2010, Miscellanea Ordinis Teutonici 1, s. 18-28.

${ }^{44}$ S. Ekdahl, W przededniu bitwy grunwaldzkiej, s. 86-88; idem, Diplomatie und die Söldnerwerbung, s. 55-58.

${ }^{45}$ Das Soldbuch des Deutschen Ordens 1410/1411. Die Abrechnungen für die Soldtruppen, cz. 1: Text mit Anhang und Erläuterungen; cz. 2: Indices mit personengeschichtlichen Kommentaren, wyd. S. Ekdahl, Köln-Weimar-Wien 1988-2010, Veröffentlichungen aus den Archiven Preussischer Kulturbesitz 23,1-2.

${ }^{46}$ Ibidem, cz. 2, s. 16-376. 
ujął dotychczasowe wyniki swoich badań nad zaciężnymi krzyżackimi z okresu wojny 1409-1411 ${ }^{47}$. Cały tom znakomicie wzbogaca naszą dotychczasową wiedzę o służbie na rzecz zakonu wielu zaciężnych rycerzy ze Śląska, Czech, Miśni, Łużyc i innych terenów Rzeszy i ich losach.

Mimo zapowiedzi S. Ekdahl nie opublikował monografii bitwy pod Grunwaldem, ale w związku z 600. rocznicą ogłosił drukiem szereg artykułów na temat kilku kluczowych momentów działań militarnych obu stron przed bitwą, jak i w trakcie starcia grunwaldzkiego. Do najważniejszych należy studium o ostatnich etapach marszu armii wielkiego mistrza i wojsk polsko-litewskich na pole bitwy i miejscu samego starcia ${ }^{48}$. Na podstawie relacji współczesnej wydarzeniom, zawartej w Franciscani Thorunensis Annales Prussici, doszedł do przekonania, iż Władysław Jagiełło stanął 13 lipca obozem koło wsi Wierzbica, na północny zachód od Jeziora Dąbrowa Mała, i że stąd wojska polskie zaatakowały i zniszczyły miasteczko Dąbrówno, a następnie nad ranem 15 lipca wyruszyły przez Samin, aby dojść pod wieś Grunwald. Natomiast siły dowodzone przez wielkiego mistrza po północy 15 lipca przemaszerowały z Lubawy przez Marwałd i Frygnowo w stronę Stębarku. Według koncepcji S. Ekdahla wojska ustawiły się po obu stronach drogi łączącej Grunwald z Łodwigowem, przy czym Krzyżacy byli od strony Stębarka, a wojska sprzymierzonych nieco na południowy zachód od Grunwaldu i na tym terenie rozegrała się bitwa. Poglądy szwedzkiego badacza w powyższej kwestii stoją w opozycji do stanowiska wielu historyków polskich, którzy przyjmują, że armia polsko-litewska z obozu na południe od Dąbrówna skierowała do w stronę Jeziora Łubień, bitwa zaś rozegrała się wzdłuż doliny Wielkiego Strumienia $^{49}$. Koncepcja S. Ekdahla stała się przedmiotem dyskusji, o czym będzie mowa niżej.

Szwedzki mediewista dokonał również zwięzłej analizy przekazów źródłowych, przede wszystkim historiograficznych, o taktyce obu walczących stron w bitwie pod Grunwaldem ${ }^{50}$. Skupił on uwagę na źródłowych informacjach o armiach i ich odwodach, rozpoczęciu starcia bitewnego, zmaganiach wojsk litewskich, wejściu do boju polskich chorągwi dla wsparcia Litwinów, ostatnim ataku sił krzyżackich z wielkim mistrzem na czele, rozstrzygnięciu bitwy, szturmie na obóz krzyżacki oraz poniesionych

${ }^{47}$ Ibidem, s. 2-11.

${ }^{48}$ S. Ekdahl, Aufmarsch und Aufstellung der Heere bei Tannenberg/Grunwald (1410). Eine kritische Analyse, w: Tradycje kulturowe i historyczne ziem pruskich, s. 31-103. Zarys tego stanowiska szwedzki badacz sformułował już w latach osiemdziesiątych ubiegłego wieku, zob. A. Nadolski, Grunwald. Wybrane problemy, s. 29-33.

${ }^{49}$ Zob. A. Nadolski, Grunwald. Wybrane problemy, s. 35-41,120-156.

50 S. Ekdahl, Quellenaussagen über die Taktik in der Tannenbergschlacht, w: Tannenberg - Grunwald - Žalgiris 1410, s. 285-300. 
przez obie armie stratach. Zdecydowanie S. Ekdahl podtrzymał koncepcję o zaplanowanej ucieczce wojsk litewskich z pola bitwy dla wyciągnięcia z niego części sił krzyżackich, uznając to za decydujący i zwrotny moment starcia grunwaldzkiego. Po raz pierwszy ten pogląd ogłosił w $1963 \mathrm{r}^{51}$

W syntetycznym ujęciu R. Czaja ukazał genezę wojny 1409-1411, jej przebieg oraz skutki dla walczących stron oraz Europy ${ }^{52}$. Podkreślił, że choć bitwa pod Grunwaldem nie spowodowała przełomu w dziejach Europy Środkowo-Wschodniej, to jednak „przyniosła istotne przewartościowanie w międzynarodowym położeniu obu stron konfliktu” oraz „zapoczątkowała długotrwały wzrost znaczenia monarchii jagiellońskiej na arenie międzynarodowej" ${ }^{53}$. Natomiast w odniesieniu do zakonu krzyżackiego wojna ta doprowadziła do załamania się jego finansów, a w dłuższej perspektywie czasu kryzysu władzy terytorialnej Krzyżaków w Prusach i konfliktu za stanami.

Pełne opracowanie kampanii 1410 r. pióra K. Kwiatkowskiego stanowi rozdział czwarty najnowszej monografii wojny $1409-1411^{54}$. Jest to niezwykle drobiazgowe i kompetentne studium wszystkich istotnych elementów składających się na kampanię letnią 1410 r., poczynając od mobilizacji sił przez obie strony konfliktu i ruchów armii królewskiej i zakonu, poprzez podejmowane próby mediacji w trakcie operacji wojskowych, bitwę pod Grunwaldem po oblężenie Malborka i wycofanie się sił polskich i litewsko-ruskich spod stolicy zakonu. W swych szczegółowych rozważaniach na temat wojsk wspomniany badacz nie podjął próby szacunkowego określenia ich liczebności, choć był to problem niezwykle żywo dyskutowany w dotychczasowej literaturze przedmiotu. Przyjął, że armia polsko-litewska była znacznie liczniejsza od sił wielkiego mistrza, ale konkretnych liczb nie podał. Natomiast zupełnie mimochodem przy kwestiach zaopatrzenia wojsk polsko-litewskich w czasie oblężenia Malborka K. Kwiatkowski uznał bez dowodów i dyskusji, że liczyły one około 40 tys. ludzi i 80 tys. koni5 ${ }^{55}$. Kontrowersyjna $\mathrm{w}$ dotychczasowej historiografii sprawa trasy marszu armii królewskiej spod Dąbrówna na pole bitwy oraz samego terenu, na którym ustawiły się oba wojska i rozegrała się batalia pod Grunwaldem, nie zostały przez K. Kwiatkowskiego jednoznacznie rozstrzygnięte i określone. Po nie-

${ }^{51}$ Ibidem, s. 291-292; S. Ekdahl, Die Flucht der Litauer in der Schlacht bei Tannenberg, „Zeitschrift für Ostforschung” 12,1963,1, s.11-19; idem, The Turning Point in the Battle of Tannenberg (Grunwald/Žalgiris) in 1410, „Lituanus. The Lithuanian Quarterly Journal of Arts and Sciences" 56, 2010, 2, s. 53-72.

${ }^{52}$ R. Czaja, Bitwa pod Grunwaldem i jej wpływ na sytuację polityczna w Europie na początku XV w., w: Wojna, pamięć, tożsamość, s. 71-79.

${ }^{53}$ Ibidem, s. 78.

${ }^{54}$ S. Jóźwiak, K. Kwiatkowski, A. Szweda, S. Szybkowski, op. cit., s. 238-563.

${ }^{55}$ Ibidem, s. 523. 
zbyt klarownej dyskusji ze stanowiskami dotychczasowej historiografii nie opowiedział się on za tradycyjną koncepcją (z pewnymi wariantami) o marszu armii polskiej spod Dąbrówna przez Jankowice, Gardyny, Turowo, Browina nad jezioro Łubień (ewentualnie przez Jankowice, Osiekowo i Łogdowo w kierunku jeziora Łubień) i ustawienia obu wojsk wzdłuż Wielkiego Strumienia. Nie zaakceptował ostatecznie również odmiennych, wyżej już przedstawionych poglądów S. Ekdahla na tę kwestię ${ }^{56}$. Jednakże w zakończeniu monografii w odniesieniu do tej samej kwestii stwierdził, że „więcej przesłanek przemawia za tezami S. Ekdahla”, dodając równocześnie, iż problem wymaga dalszych badañ ${ }^{57}$. Szkoda, że w tej monumentalnej pracy toruński mediewista uchylił się od precyzyjnej odpowiedzi w tak zasadniczych sprawach. Również i inne problemy związane ze starciem grunwaldzkim nie zostały szczegółowo omówione, ponieważ Autor uznał arbitralnie, że „pełna prezentacja obrazu bitwy grunwaldzkiej, obecnie dość zróżnicowanego w szczegółach, nie jest w ramach tej książki ani konieczna, ani tym bardziej właściwa - z przyczyn kompozycyjnych"58. Czytelnikowi trudno przyjąć te argumenty, gdyż „wyważenie proporcji analitycznych i narracyjnych" względem „wszystkich pozostałych wypadków składających się na wojnę 1410-1411 r. w ogólności i wyprawę letnią 1410 r. w szczególności" ${ }^{59}$ powinno ustąpić wobec wagi problemu bitwy grunwaldzkiej. Fazy starcia bitewnego zostały przez K. Kwiatkowskiego dość solidnie ukazane z zaznaczeniem wątpliwości dotyczących chronologicznego uporządkowania szeregu epizodów. Zasadnie podważył tezę niektórych badaczy, w tym S. Ekdahla, o „pozorowanej ucieczce” sił litewsko-ruskich z pola bitwy w celu odciągnięcia części oddziałów zakonnych, która miała decydująco zaważyć na losach całej batalii, wskazując, że ta ucieczka miała charakter rzeczywisty i była wynikiem przewagi krzyżackiej nad wojskami litewskimi. Wiele uwagi poświęcił Autor zagadnieniu strat poniesionych przez obie walczące w bitwie grunwaldzkiej. Skrupulatnie zestawił informacje źródłowe o poległych i wziętych do niewoli z armii wielkiego mistrza oraz zabitych po stronie polsko-litewskiej, ale znów w konkluzji stwierdził, że „podstawa źródłowa nie pozwala na ich dokładne określenie". Zdystansował się też od dotychczasowych szacunków badaczy, a unikając podania konkretnych liczb, podkreślił, że „jedynie

${ }^{56}$ Ibidem, s. 373-401. W konkluzji stwierdził: „Kończąc prezentację poglądów dotyczących marszruty sił królewskich rankiem 15 lipca, trzeba ponownie zaznaczyć, że koncepcja S. Ekdahla w swojej najnowszej (a zarazem pierwotnie wykoncypowanej) postaci jest - jak to już ukazano - nie do przyjęcia” (s. 401).

${ }^{57}$ Ibidem, s. 753.

${ }^{58}$ Ibidem, s. 386.

${ }^{59}$ Ibidem. 
pewnym stwierdzeniem pozostać może to dotyczące relatywnie wysokich strat wśród braci zakonnych, które proporcjonalnie znacznie przewyższały straty poniesione przez pozostałych zbrojnych walczących w wojsku wielkiego mistrza. Równie pewny wydaje się być sąd o relatywnie nieznacznej liczbie poległych w wojsku koronnym i o dość wysokich stratach

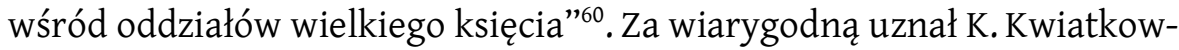
ski tylko liczbę 203 (lub 211) poległych braci zakonnych wymienioną w anniwersarzu z komturii krzyżackiej w Maastricht, którą zweryfikował, odejmując trzech (Markwarda von Salzbach, Fryderyka von Schönberg i Jerzego Marschalka), ściętych z rozkazu Witolda w kilka dni po bitwie (20 lipca).Co godne podkreślenia, Autor zdołał niezbicie ustalić, że niektórzy bracia rycerze biorący udział w bitwie przeżyli ją i są poświadczeni w późniejszych źródłach. W ten sposób zakwestionował on pogląd, że starano się ich wszystkich zabić w czasie starcia bitewnego. W kontekście średniowiecznej kultury dworskiej oraz obyczaju rycerskiego K. Kwiatkowski omówił problem trzydniowego pobytu zwycięskiej armii na polach grunwaldzkich i rozprawił się gruntownie z rozpowszechnionym przekonaniem, że pozostanie króla na pobojowisku przyczyniło się do utraty szansy zdobycia Malborka. Obliczył, że Henryk von Plauen, komtur świecki, zdołał zgromadzić w twierdzy malborskiej do 23 lipca ponad 3200 zbrojnych $^{61}$. Zakwestionował też stanowisko, jakoby po wiktorii grunwaldzkiej Jagiełło świadomie dążył do likwidacji władztwa krzyżackiego w Prusach, ale nie próbował odpowiedzieć na pytanie o możliwe wówczas cele, do których zmierzali król i wielki książę. Następnie Autor ukazał pochód sił polsko-litewskich pod Malbork, który wiązał się również z przejmowaniem władztwa nad poddającymi się królowi miastami i zamkami w Prusach. W końcu omówił szczegółowo oblężenie zamku malborskiego i próby jego zdobycia oraz aktywność militarną obu stron, a także przyczyny zwinięcia oblężenia i powrót wojsk do Korony i na Litwę (sam Jagiełło z oddziałami nadwornymi i zaciężnymi pozostał na pograniczu państwa zakonnego). Te wywody zwieńczył analizą sytuacji w Prusach po wycofaniu się armii polsko-litewskiej spod Malborka.

Dyskusję z poglądami S. Ekdahla, A. Nadolskiego i K. Kwiatkowskiego w sprawie ostatniego etapu drogi wojsk polsko-litewskich pod Grunwald podjął Tadeusz Grabarczyk ${ }^{62}$. Autor szczegółowo rozważył koncepcje mediewistów na ten temat i zaproponował własną hipotezę. Stwierdził, że armia polsko-litewska spod Dą̧brówna skierowała się na wschód, aby dotrzeć

${ }^{60}$ Ibidem, s. 449.

${ }^{61}$ Ibidem, s. 488.

${ }^{62}$ T. Grabarczyk, Armia króla Władysława Jagiełty w drodze pod Grunwald, w: Bitwa pod Grunwaldem w historii i tradycji Polski i Litwy, s. 7-25. 
w rejon Olsztynka. Część oddziałów wykorzystała szlak na Turowo-Zybułtowo, znaczna zaś część wojska dostała się w rejon Zybułtowa przez Osiekowo i Łogdowo, a potem skierowały się one na Stębark lub Ulnowo, a więc drogami na zachód od jeziora Łubień. Nawiązuje ona do poglądów S. M. Kuczyńskiego oraz Wiesława Majewskiego ${ }^{63}$. Ta interesująca koncepcja domaga się jednak rzetelnej dyskusji naukowej i wkomponowania w dalszy bieg wypadków na polach Grunwaldu, poczynając od miejsca ustawienia się obu armii przed rozpoczęciem bitwy, albowiem w tej ważnej kwestii T. Grabarczyk nie zajął już jasnego stanowiska, wspominając tylko rozbieżne poglądy S. Ekdahla i A. Nadolskiego, o których była mowa wyżej.

Natomiast Jerzy Rajman w obszernym artykule przeprowadził wieloaspektową analizę przekazów historiograficznych krzyżackich i polskich o bitwie grunwaldzkiej ${ }^{64}$. W szczególności skupił się relacjach zawartych w takich źródłach, jak: Kronika konfliktu, Kontynuacja kroniki Jana z Reden, Annalista toruński, Annales i Banderia Prutenorum Długosza. Konfrontując rezultaty własnych analiz źródłowych z koncepcjami historyków na temat liczebności i składu obu armii na polach Grunwaldu, przebiegu bitwy oraz poszczególnych jej etapów, a także strat wojsk zakonnych i polsko-litewskich, Autor starał się sprowadzić dyskusję nad rozmaitymi szczegółowymi problemami na grunt wiarygodnych źródeł, eksponując na pierwszym planie Kronikę konfliktu. Wykazał on również wiarygodność wielu informacji o bitwie w Annales Długosza, oddzielając je od przyjętych przez tego historiografa założeń i koncepcji, w które wkomponował swój obraz bitwy pod Grunwaldem. Konstatacje J. Rajmana mają istotne znaczenie w dyskusji nad wiarygodnością przekazu Długosza zwłaszcza wobec hiperkrytycznej postawy S. Ekdahla i po części K. Kwiatkowskiego względem relacji krakowskiego dziejopisarza.

Należy również odnotować prace K. Kwiatkowskiego i Stefana Kwiatkowskiego poświęcone oddziaływaniu klęski armii zakonu pod Grunwaldem na mentalność społeczeństwo pruskiego i samych uczestników bitwy. Pierwszy z tych badaczy skupił się na percepcji przegranej zakonu przez społeczeństwo pruskie oraz uczestników starcia (głównie jeńców) w pierwszych dniach po bitwie i podjął próbę określenia reakcji społecznych na $\mathrm{klęskę}^{65}$.Z kolei S. Kwiatkowski ukazał Grunwald jako potężny wstrząs dla

${ }^{63}$ Ibidem, s. 21-22.

${ }^{64}$ J. Rajman, Czy duchowni kronikarze potrafili opisać „wielkie starcie”? Uwagi o bitwie, liczebności i stratach obu armii w świetle źródet i nowszej historiografii polskiej, w: Bitwa pod Grunwaldem w historii i tradycji Polski i Litwy, s. 26-74.

${ }^{65} \mathrm{~K}$. Kwiatkowski, Pierwsze wrażenia $w$ Prusach po porażce zakonu niemieckiego $w$ bitwie grunwaldzkiej, ZH 75, 2010,2, s. 47-66. 
uczestniczących w bitwie oraz poddanych zakonu w dłuższej perspektywie czasu $^{66}$. Omówił przy tym rolę pobojowiska i pogrzebów poległych w potęgowaniu wrażenia klęski, a następnie kwestię fundacji na polu bitewnym króla Jagiełły (niezrealizowanej) i wielkiego mistrza Henryka von Plauena oraz powszechne modlitwy o pokój po zakończeniu wojny, a także problem pokuty społeczeństwa pruskiego z powodu wiarołomstwa okazanego panom zakonnym. Z kolei udział Rusinów w starciu grunwaldzkim i echa bitwy w ruskich latopisach i środowiskach prawosławnych przedstawił Henadź Sahanovič (Genadz' Saganovič $)^{67}$.

Dalszy przebieg zmagań wojennych od zwinięcia oblężenia Malborka do zawarcia traktatu pokojowego w Toruniu został szczegółowo omówiony w dwóch ostatnich rozdziałach monografii wojny 1409-1411 czterech autorów. Najpierw A. Szweda zaprezentował zmagania dyplomatyczno- propagandowe obu stron konfliktu na forum międzynarodowym, a potem negocjacje rozejmowe, K. Kwiatkowski zaś starcia zbrojne polsko-krzyżackie i politykę nowo wybranego wielkiego mistrza Henryka von Plauena ${ }^{68}$. Natomiast S. Szybkowski szczegółowo ukazał konflikt polsko-węgierski i wyprawę wojsk Zygmunta Luksemburskiego na południową Małopolskę po 24 października 1410 r., która była wypełnieniem sojuszniczych zobowiązań króla węgierskiego wobec zakonu. Wspomniany badacz omówił również kontrakcję Małopolan zakończoną zwycięstwem wojsk polskich pod Bardiowem i spustoszeniem pogranicznych ziem Górnych Węgier. Przy tej okazji warto wspomnieć o edycjach ważnego źródła węgierskiego z wykazem chorągwi (i ich liczebności - kopijników) stacjonujących na pograniczu węgiersko-polskim od września-października 1410 r., które wzięły udział w ataku na Sądecczyznę. Autor przytoczył informacje z tego źródła za badaczką słowacką Danielą Dvořákovą, pełnego zaś wydania z komentarzem dokonał Norbert C. Tóth, a dla polskich mediewistów uprzystępnił tę edycję Stanisław A. Sroka ${ }^{69}$. W ostatnim rozdziale wspomnianej monografii ${ }^{70}$ najpierw S. Szybkowski scharakteryzował postawy polskich i litewskich elit wobec konfliktu z zakonem krzyżackim w czasie

${ }^{66}$ S. Kwiatkowski, Pamięć, żałoba, pojednanie. Bitwa grunwaldzka jako wstrzas w mentalności jej uczestników i ludności Prus zakonnych, w: Wojna, pamięć, tożsamość, s. 90-106.

${ }^{67}$ H. Sahanovič, Tannenberg und die ostslawische orthodoxe Welt, w: Tannenberg Grunwald - Žalgiris 1410, s. 309-320.

${ }^{68}$ S. Jóźwiak, K. Kwiatkowski, A. Szweda, S. Szybkowski, op. cit., s. 564-693.

${ }^{69}$ D. Dvořáková, Rytier a jeho král. Stíbor zo Stiboríc a Žigmund Luxemburský, Budmerice 2003, s. 288-289; N.C. Tóth, Az 1395. évi lengyel betörés. A lengyel-magyar kapcsolatok egy epizódja, w: Honoris causa. Tanulmáyok Engel Pál tiszteletére, red. T. Neumann, G. Rácz, Budapest-Pilicsaba 2009, s. 480-484; S. A. Sroka, Wojska węgierskie u granic Polski w 1410 roku, SH 53, 2010, 3, s. 340-345.

${ }^{70}$ S. Jóźwiak, K. Kwiatkowski, A. Szweda, S. Szybkowski, op. cit., s. 694-747. 
trwania wojny w 1410 i na początku 1411 r., stwierdzając, że po sukcesie letniej wyprawy na Prusy „możni i szlachta polska szybko stracili zainteresowanie wojną", a dalsze wysiłki militarne Jagiełły wspierali niektórzy panowie wielkopolsko-kujawscy i dostojnicy dworscy ${ }^{71}$. Gdański mediewista uznał to słusznie za jedną z ważnych przyczyn obok utraty większości zamków w Prusach i powrotu tamtejszej ludności pod zwierzchnictwo zakonu i decyzji króla o zakończeniu wojny i zawarciu traktatu pokojowego. Z kolei negocjacje pokojowe i położenie militarne obu stron na przełomie stycznia i lutego 1411 r. przedstawili A. Szweda i K. Kwiatkowski, natomiast traktat toruński kończący wojnę stał się przedmiotem analiz A. Szwedy ${ }^{72}$. Ocena tego układu pokojowego i jego skutków, budząca w dotychczasowej historiografii wiele dyskusji, została dokonana w niniejszym dziele niezwykle rzeczowo, w szerokim kontekście sytuacji obu stron konfliktu na początku $1411 \mathrm{r}^{73}$ Omawiając realizację postanowień traktatu, autorzy podkreślili, że obie strony już po kilku miesiącach zaprzestały wypełniania jego warunków, a spór polsko-krzyżacki został oddany do rozstrzygnięcia Zygmuntowi Luksemburskiemu.

Niektóre aspekty ostatniej fazy wojny oraz jej skutków, a także działania króla Władysława zmierzające do upamiętnienia zwycięstwa zostały podjęte przez badaczy w osobnych pracach. Tak więc S. Jóźwiak zajął się problemem około 300 jeńców strony krzyżackiej wziętych do niewoli przez polskie rycerstwo w bitwie pod Koronowem, śledząc ich los aż do uzyskania wolności ${ }^{74}$. Interesujące badania nad korzyściami odniesionymi przez polskich rycerzy uczestników wojny przeprowadził Jerzy Sperka ${ }^{75}$.Zdołał ustalić, że 26 rycerzy otrzymało od króla dobra (wsi lub zapisy na dobrach) za zasługi wojenne, a kilkunastu dostało nominacje na urzędy lub awanse na wyższe hierarchicznie dostojeństwa. Ponadto w jednostkowych przypadkach (np. Jakuba z Kobylan i Mikołaja Chrząstowskiego) wykazana w bitwach odwaga umożliwiła rycerzom odzyskanie łaski królewskiej. Równocześnie J. Sperka skonstatował, że niemożliwa jest do określenia grupa rycerstwa polskiego, która wzbogaciła się poprzez łupy zdobyte w Prusach. Z kolei Wojciech Fałkowski w gruntownym studium omówił

${ }^{71}$ Ibidem, s. 702-703.

${ }^{72} \mathrm{~W}$ odrębnym studium A. Szweda omówił wszystkie dokumenty wystawione przez obie strony przy zawieraniu rozejmów w okresie wojny 1409-1411 oraz pokoju toruńskiego, a także losy tych dokumentów. Zob. idem, Uwagi o dokumentach rozejmowych i pokojowych z okresu wojny 1409-1411, ZH 75, 2010, 2, s. 67-85.

${ }^{73}$ S. Jóźwiak, K. Kwiatkowski, A. Szweda, S. Szybkowski, op. cit., s. 712-721.

${ }^{74}$ S. Jóźwiak, Jeńcy strony krzyżackiej po bitwie pod Koronowem, ZH 75, 2010, 2, s. $87-102$.

${ }^{75} \mathrm{~J}$. Sperka, Beneficjenci Wielkiej wojny wśród rycerstwa polskiego, w: Bitwa pod Grunwaldem $w$ historii i tradycji Polski i Litwy, s. 92-111. 
uroczysty powrót zwycięskiego króla Jagiełły do stołecznego Krakowa w dniu 25 listopada $1411 \mathrm{r}$. w kontekście średniowiecznego rytuału adventus regis ${ }^{76}$. Wówczas monarcha w otoczeniu panów i prałatów, poprzedzany zdobytymi chorągwiami krzyżackimi pieszo udał się najpierw na Skałkę dla uczczenia św. Stanisława, a następnie do katedry na Wawelu, gdzie złożył owe chorągwie. Wspomniany badacz zwrócił uwagę na liczne odniesienia symboliczne i ideowe rytuału pieszego powrotu władcy po zwycięstwie, sięgające ideologii królewskiej z czasów karolińskich, a także podkreślił jego rolę we wzmocnieniu autorytetu i prestiżu monarszego.

Pogrunwaldzkie fundacje Jagiełły budzą interesowanie mediewistów, choć brak dotąd w literaturze pełnego ujęcia tego problemu. Obecna rocznica przyczyniła się do powstania artykułu S. Ekdahla o fundacji klasztoru brygidek w Lublinie w latach 1412-1426 dokonanej przez króla Władysława ${ }^{77}$. Z kolei niedawno odkryty w prezbiterium katedry sandomierskiej fryz heraldyczny Tomisław Giergiel uznał za wspólną pogrunwaldzką fundację Jagiełły i Anny Cylejskiej ${ }^{78}$.

Skromny dorobek historiografii rocznicowej odnotować należy w zakresie edycji nowych, nieznanych dotąd źródeł. K. Kwiatkowski odkrył w dziale rękopisów Biblioteki Litewskiej Akademii Nauk im. Wróblewskich (Lietuvos mokslu akademijos Vrublevskiu biblioteka) w Wilnie kodeks pruskiej proweniencji z pierwszej połowy XVI w. zawierający około 1725 nieznanych dotąd historykom regestów wewnętrznej korespondencji zakonu krzyżackiego oraz nielicznych dokumentów z lat 1270-1497 ${ }^{79}$. Toruński mediewista ustalił, że 58 regestów listów krzyżackich dotyczy okresu wojny 1409-1411, z czego opublikował $39^{80}$. Przynoszą one materiał zupełnie nowy, całkiem nieznany badaczom, który poważnie dopełnia informacje źródłowe o tej wojnie.

Rocznica przyczyniła się do ponownej edycji przez Bibliotekę Jagiellońską (z reprodukcjami wszystkich kart rękopisu) dzieła Długosza i Stanisława Durinka Banderia Prutenorum i ożywienia dyskusji nad tym ważnym źródłem do dziejów wojskowości w państwie zakonu krzyżackiego

${ }^{76}$ W. Fałkowski, Adventus regis. Powrót Władysława Jagiełly do Krakowa po zwycięstwie grunwaldzkim, RH 76, 2010, s. 77-102.

${ }^{77}$ S. Ekdahl, St Brigitta of Sweden, the Battle of Tannenberg (Grunwald) and the Foundation of the Monastery Triumphus Mariae in Lublin, w: Między Ślaskiem a Wiedniem. Księga jubileuszowa z okazji 60. urodzin prof. dr. hab. Krzysztofa A. Kuczyńskiego, red. A. Kozłowski, M. Znyk, Płock 2008, s. 287-301.

${ }^{78}$ T. Giergiel, Pogrunwaldzka fundacja Władysława Jagiełty i Anny Cylejskiej, w: Bitwa grunwaldzka whistorii, tradycji i kulturze, s. 49-66.

${ }^{79}$ K. Kwiatkowski, Neue Quellen aus dem Kreis des Deutschen Ordens zum Krieg von 1409-1411, cz. 1, ZH 75, 2010, 4, s. 67-78, 112.

${ }^{80}$ Ibidem, Quellenmaterial (Regesten), s. 79-111. 
i kampanii $1410 \mathrm{r}^{81}$ Obszerny wstęp do tego wydania opracował Krzysztof Stopka, który krytycznie zrekapitulował dotychczasowe badania nad rękopisem, ukazując proces tworzenia dzieła, autorów oraz losy kodeksu do czasów współczesnych ${ }^{82}$. W związku z tą edycją Jan Ptak zajął się oraz rozmaitymi aspektami źródłoznawczymi Banderiów, jak i ich unikalnym charakterem jako źródła do badań z zakresu weksylologii i wojskowości średniowiecznej ${ }^{83}$. Natomiast Magdalena Adamska omówiła wszystkie istniejące i zaginione kopie oraz edycje Banderiów od XVI do początku XXI w. ${ }^{84}$

\section{Tradycja grunwaldzka}

W literaturze rocznicowej znacznym zainteresowaniem badaczy cieszyły się tematy związane ze zróżnicowaną tradycją grunwaldzką w Polsce, na Litwie i Białorusi oraz w Niemczech i jej funkcjonowaniem od XV do początku XXI w. Należy tu wymienić zwłaszcza pierwszy tom Katalogu wystawy: Na znak świetnego zwycięstwa, zawierający kilka interesujących studiów poświęconych tej problematyce. Główne linie rozwoju polskiej tradycji związanej z wiktorią grunwaldzką od jej narodzin w propagandowych działaniach kancelarii królewskiej skierowanych bezpośrednio po bitwie do wpływowych środowisk w Królestwie Polskim i poza jego granicami aż po XVII stulecie znakomicie nakreślił Marek A. Janicki ${ }^{85}$. Poddał on analizie łacińskie kazania i mowy, dzieła historiograficzne, utwory wierszowane, poemat Jana z Wiślicy, Bellum Prutenum, poezję dworską i panegiryczną, polskie pieśni i poezję, źródła ikonograficzne, liturgiczne, a także podkreślił przemożną rolę katedry wawelskiej jako najważniejszego ośrodka kultywowania tradycji grunwaldzkiej w tym okresie. Poemat Jana z Wiślicy, dedykowany królowi Zygmuntowi I Staremu w 1516 r., stał się przedmiotem pogłębionych badań Pawła Żmudzkiego, który starał się podaną przez autora wizję batalii grunwaldzkiej usytuować w kontekście ówczesnej historiografii $^{86}$. Z kolei ks. Jan Józef Janicki omówił zwięźle liturgiczne

${ }^{81}$ Banderia Prutenorum, red. Z. Pietrzyk, Proszówki-Kraków 2009.

${ }^{82}$ K. Stopka, Na wieczna pamiatkę i symbol. Banderia Prutenorum: dzieło, autorzy, losy, w: Banderia Prutenorum, s. 13-46.

${ }^{83} \mathrm{~J}$. Ptak, Banderia Prutenorum. Pogrunwaldzka pamiattka w kulturze polskiej, w: Bitwa grunwaldzka w historii, tradycji i kulturze, s. 77-100.

${ }^{84}$ M. Adamska, Kopie i edycje kodeksu „Banderia Prutenorum”, w: Na znak świetnego zwycięstwa, t. 1, s. 155-184.

${ }^{85}$ M. A. Janicki, Grunwald w tradycji polskiej od XV do XVII wieku, w: Na znak świetnego zwycięstwa, t. 1, s. 89-154.

${ }^{86}$ P. Żmudzki, Jak opisać bitwe pod Grunwaldem? Bellum Prutenum Jana $z$ Wiślicy na tle historiografii średniowiecznej, w: Wojna, pamięć, tożsamość, s. 108-129. 
aspekty obchodów święta Rozesłania Apostołów w Polsce od 1411 r. do początku XIX w..$^{87}$ Natomiast Krzysztof J. Czyżewski ukazał rozmaite formy upamiętnienia wielkich zwycięstw polskiego oręża w katedrze na Wawelu od średniowiecza do czasów współczesnych, od liturgicznych poczynając, poprzez wota i zwycięskie trofea, a na artystycznych kończąc ${ }^{88}$.Jerzy T.Petrus w obszernym studium zbadał ikonografię króla Władysława Jagiełły aż do początku XX w. ${ }^{89}$ Wykazał, że przez prawie trzy wieki rozwijała się ona $\mathrm{w}$ trzech nurtach zapoczątkowanych przez rzeźby nagrobka w katedrze wawelskiej, obraz fundacyjny w kaplicy Świętego Krzyża w Lublinie oraz wizerunek na pieczęci majestatycznej, a w XIX stuleciu powstały romantyczne, wręcz bajkowe wizje postaci króla odległe od dotychczasowej tradycji. Marek Walczak prześledził stosunkowo skromną ikonografię bitwy grunwaldzkiej w sztuce późnośredniowiecznej i nowożytnej, podnosząc, że najstarsze jej przedstawienia pochodzą z ostatniej ćwierci XV w. z dwóch kronik berneńskich Diepolda Schillinga zw. Starszym, a dopiero potem pojawiają się w nowożytnej historiografii pruskiej ${ }^{90}$. Z kolei motywy grunwaldzkie w polskim malarstwie od końca XVIII do początków XX w. oraz krakowskie obchody w 1910 r. i powstanie pomnika grunwaldzkiego Antoniego Wiwulskiego omówiła Agnieszka Janczyk ${ }^{91}$.

Tradycja historiograficzna bitwy grunwaldzkiej (i szerzej wojny 1409-1411) w poszczególnych krajach i jej związki z polityką oraz ideologią narodową i państwową stały się także obiektem rocznicowego zainteresowania badaczy. Temat Grunwaldu w tradycji litewskiej, białoruskiej i sowieckiej XX w. ukazał wnikliwie R. Petrauskas, podnosząc, że pamięć o tym zwycięstwie ściśle splatała się wówczas ze stanem świadomości narodowej i historycznej na Litwie, a w okresie przynależności do Związku Radzieckiego z retoryką i polityką sowiecką ${ }^{92}$.Zauważył też powolne zmiany w litewskiej kulturze historycznej po 1990 r., kiedy to pamięć o Grunwaldzie stała się podatniejsza na wyniki dociekań naukowych. Analizę porównawczą mitów, wyobrażeń i funkcji pamięci o bitwie grunwaldzkiej

${ }^{87}$ J.J. Janicki, Liturgiczne obchody święta Rozesłania Apostołów upamiętnieniem zwycięstwa nad Krzyżakami, w: Na znak świetnego zwycięstwa, t. 1, s. 41-52.

${ }^{88}$ K.J. Czyżewski, Marsowe echa w katedrze krakowskiej, w: Na znak świetnego zwycięstwa, t. 1, s. 53-88.

${ }^{89}$ J. T. Petrus, Ikonografia króla Władysława Jagiełty, w: Na znak świetnego zwycięstwa, t. 1, s. 221-268; idem, Portrety króla Władysława Jagiełły, Kraków 2010.

${ }_{90} \mathrm{M}$. Walczak, Bitwa grunwaldzka a sztuka od wieku XV do końca XVIII, w: Na znak świetnego zwycięstwa, t. 1, s.269-302.

${ }^{91}$ A. Janczyk, „Grunwald, miecze, król Jagiełło” - tradycja grunwaldzka w okresie zaborów, w: Na znak świetnego zwycięstwa, t. 1, s. 303-350.

${ }^{92}$ R. Petrauskas, Grunwaldu życie pośmiertne od XV do XX w. whistoriografii i tradycji litewskiej, białoruskiej i sowieckiej, w: Wojna, pamięć, tożsamość, s. 147-164. 
w XX w. w Polsce i na Litwie przeprowadzili Alvydas Nikžentaitis i Živilè Mikailien $\dot{e}^{93}$. Natomiast w odniesieniu do Polski i Niemiec problemem tradycji o Grunwaldzie/Tannenbergu w XIX i XX w. zajmowali się z okazji rocznicy Udo Arnold, S. Ekdahl, Stefan Dyroff i Krzysztof Baczkowski ${ }^{94}$. Przy tej okazji dokonano także bilansu dorobku historiografii litewskiej i polskiej w zakresie badań nad bitwą grunwaldzką ${ }^{95}$. Poruszano również kwestię ujęć bitwy pod Grunwaldem w polskich i litewskich podręcznikach szkolnych do historii ${ }^{96}$. Ponadto powstało szereg artykułów poświęconych tematyce obchodów rocznicowych w 1910 i 1960 r., które ukazują ich odmienny kontekst historyczny, ideowy, polityczny i propagandowy oraz echa tych uroczystości ${ }^{97}$. W końcu uwaga badaczy skupiła się też na filmie Aleksandra Forda Krzyżacy oraz współczesnych rekonstrukcjach bitwy na polach Grunwaldu ${ }^{98}$.

${ }^{93}$ A. Nikžentaitis, Ž. Mikailienè, Litewski Žalgiris, polski Grunwald: dwa toposy narodowe w kontekście analizy porównawczej, ZH 75, 2010, 2, s. 7-21; zob. też A. Nikžentaitis, Internationales Gedenken an die Schlacht bei Tannenberg, w: Tannenberg - Grunwald - Žalgiris 1410, s. 321-328.

${ }^{94}$ U. Arnold, Tannenberg/Grunwald als politisches Symbol im 19./20. Jahrhundert, w: Tradycje kulturowe, s. 7-18; S. Ekdahl, Bitwa pod Grunwaldem/Tannenbergiem w polsko-niemieckiej historii na przestrzeni dziejów, w: Jana Matejki Bitwa pod Grunwaldem. Nowe spojrzenia, red. K. Murawska-Muthesius, Warszawa 2010, s. 9-25; S. Dyroff, Grunwald w historiografii i tradycji polskiej oraz niemieckiej, w: Wojna, pamięć, tożsamość, s. 130-146; idem, Grunwald in den deutschen und polnischen Historiografien sowie Traditionen, „Historie. Jahrbuch des Zentrums für Historische Forschung Berlin der Polnischen Akademie der Wissenschaften" 3, 2009/2010, s. 204-222; K. Baczkowski, Grunwald w tradycji i historiografii narodowej polskiej, Kraków 2010, s. 5-24.

${ }^{95} \mathrm{~T}$. Baranauskas, Bitwa pod Grunwaldem w pracach historyków litewskich, w: Bitwa pod Grunwaldem w historii i tradycji Polski i Litwy, s. 75-91; S. Jóźwiak, Rozwój badań nad wielka wojna, s. 209-223.

${ }^{96}$ I. Gancewska, Ilustracja i narracja bitwy grunwaldzkiej w nauczaniu szkolnym po II wojnie światowej w Polsce do 1999 roku, w: Tradycje kulturowe, s. 105-114; A. Chłosta-Sikorska, Bitwa pod Grunwaldem w polskich podrecznikach do historii, w: Bitwa pod Grunwaldem $w$ historii i tradycji Polski i Litwy, s. 147-169; D. Karvelis, Wizerunek bitwy pod Grunwaldem w podręcznikach szkolnych Litwy z lat 1906-2010, w: Bitwa pod Grunwaldem w historii i tradycji Polski i Litwy, s. 135-146.

${ }^{97}$ M. Sala, Krakowskie obchody 500. rocznicy bitwy grunwaldzkiej w świetle prasy austriackiej, w: Bitwa grunwaldzka w historii, tradycji i kulturze, s. 129-140; J. Hampel, Uwarunkowania rozwoju tradycji grunwaldzkiej w XIX i na poczatku XX wieku, w: Bitwa pod Grunwaldem w historii i tradycji Polski i Litwy, s. 126-134; G. Miernik, Obchody 550. rocznicy bitwy pod Grunwaldem. Studium propagandy politycznej PRL, w: Bitwa grunwaldzka w historii, tradycji i kulturze, s. 141-165; L. Gorycki, Tradycja grunwaldzka w Polsce po 1918 roku. Między polityczna koniecznościa a społecznym oczekiwaniem, w: Bitwa pod Grunwaldem whistorii i tradycji Polski i Litwy, s. 170-185.

${ }^{98}$ B. Skowronek, Film Krzyżacy Aleksandra Forda. W uścisku rozmaitych ideologii, w: Bitwa pod Grunwaldem w historii i tradycji Polski i Litwy, s. 186-194; M. Bator, „Zbiór przypadkowych starć i pojedynków” czy „źródło ciekawych rozwiązań artystycznych”? - sekwencja 
Powyższy wybiórczy z konieczności przegląd dorobku rocznicowego dowodzi, że naukowo nie został on zmarnowany. Różnorodne inicjatywy badawcze głównie polskich, niemieckich i litewskich środowisk naukowych przyniosły trwałe owoce. Do fundamentalnych osiągnięć należy kompleksowa monografia wojny 1409-1411 autorstwa czterech polskich mediewistów oraz szereg odrębnych studiów dotyczących kampanii letniej 1410 r., w tym bitwy pod Grunwaldem i jej skutków, które zdecydowanie pogłębiają i poszerzają dotychczasową wiedzę nie tylko o samych wydarzeniach, ale również o ich europejskim kontekście politycznym, kulturowym i ideowym. Ponadto intensywnymi badaniami objęta została różnorodna w treści, formach i funkcjach tradycja grunwaldzka w Polsce, na Litwie, Białorusi i w Niemczech aż po początek XXI w. Jednak $w$ tej sferze zabrakło obszerniejszych monograficznych ujęć.

bitwy pod Grunwaldem w filmie Aleksandra Forda „Krzyżacy”, w: Bitwa grunwaldzka w historii, tradycji i kulturze, s. 167-174. 